\title{
Discovery of columbite in the environs of limoges
}

\section{Damour}

To cite this article: M. Damour (1848) Discovery of columbite in the environs of limoges, Philosophical Magazine Series 3, 33:225, 553-554, DOI: $10.1080 / 14786444808646163$

To link to this article: http://dx.doi.org/10.1080/14786444808646163

曲 Published online: 30 Apr 2009.

Submit your article to this journal

LII Article views: 1

Q View related articles $₫$ 


\section{DISCOVERY OF COLUMBITE IN THE ENVIRONS OF LIMJGES. BY M. DAMOUR.}

The specimen of this substance was found in a quarry near Chanteloube, belonging to M. Alluaud, Sen., collected by M. Mathieu, a mineral dealer of Paris, and confounded with specimens of wolfram, triplite, heterosite and dufrenite, brought from the same place.

Its colour, hardness and great density, induced M. Damour to think that it did not belong to any of the preceding species; and a qualitative examination proved that it was almost entirely composed of columbic acid and oxide of iron, with a small quantity of oxide of tin.

This specimen had the form of amorphous nucleus, of the size of a hazel-nut, imbedded in yellowish-white felspar. Superficially it was of a tarnished bluish-black colour, with a shining, smooth fresh fracture The powder was of a grayish-black colour. It scratches glass readily ; its density was found to vary from 7·640 to 7•65l. It is infusible by the blowpipe. When reduced to powder and mixed with tartrate of potash and carbonate of soda, it fuses on charcoal, and yields some globules of tin. When fused with borax and phosphoric salt, it reacts like iron. Acids do not act upon it.

To analyse this mineral, it was reduced to powder and fused with eight times its weight of bisulphate of potash, and the fused mass when cold was treated with a large quantity of hot water. The oxides of iron and tin were almost entirely dissolved in the liquor: the columbic acid was deposited in the form of a white powder, but still retaining a little oxide of tin and iron. It was digested in hydrosulphate of ammonia, by which the oxide of iron was converted into an insoluble sulphuret, and the sulphuret of tin remained dissolved in the sulphurous ammoniacal liquor, which was filtered and saturated with acetic acid, and the sulphuret of tin precipitated was collected. The columbic acid, blackened by the sulphuret of iron, was treated with hydrochloric acid; by this the iron was dissolved, and the columbic acid after washing was perfectly white; it was dried, ignited and weighed.

The liquor separated from the sulphuret of tin was treated with ammonir and its hydrosulphate; by this all the iron was obtained in the state of sulphuret; the liquor separated from it contained no earthy base whatever.

The sulphuret of iron was dissolved in aqua regia; by evaporating the solution and treating the residue with water, a minute quantity of silica was left. The ferruginuus liquor was saturated with ammonia, and the quantity of protoxide of iron was inferred from that of the peroxide obtained.

100 parts of the mineral yielded-

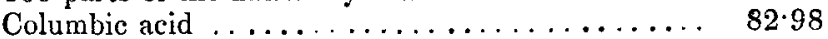

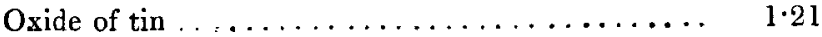

Protoxide of iron with a trace of oxide of manganese 14.62

Silica . . . . . . . . . . . . . . . . . $\frac{0.42}{99 \cdot 23}$

M. Damour observes, that although the columbic acid is reckoned as pure, it may possibly contain a small quantity of the niobic and

Phil. Mag. S. 3. No. 225. Suppl. Vol. 33. 
pelopic acids recently discovered by $M$. Rose in the columbiferous minerals of Bavaria and America. The columbite of Limoges is denser than these, of which the former has a density of $6.590,6 \cdot 078,5 \cdot 976$, and the latter of $5 \cdot 708,5 \cdot 495$. That of Tamela in Finland, which M. Rose considers as pure columbic acid, is of density, $7 \cdot 197,7 \cdot 476$, 7.510.-Annales des Mines, tome xiii.

\section{ON alluaUdTE, -A NEW PHOSPHATE OF IRON, MANGANESE AND SODA. BY M. A. DAMOUR.}

This substance was recently found imbedded in pigmatite near Limoges.

Its colour when viewed in mass is clove-brown; its fracture is laminated and shining, and in some parts, which seem to have undergone some alteration, it is chatoyant like hyperstene. Fracture indicates a right rectangular prism as its crystalline form. It scratches fluor spar, and is scratched by a steel point; the powder is brownish-yellow. Its density is 3.468 .

Moderate-sized specimens appear occasionally to contain accidental admixtures of peroxide of iron and black oxide of manganese : they are sometimes associated with green phosphate (dufrenite) and blue phosphate of iron.

$\mathrm{By}$ the blowpipe, in platina forceps, this mineral fuses very readily with intumescence, into a black globule, which is not magnetic; in the oxidizing flame, it dissolves entirely in phosphoric salt and indicates manganese; heated in a tube, it decrepitates and disengages a small quantity of neutral water.

When in fine powder it dissolves readily in cold hydrochloric acid; the solution at first is of a blackish colour and evolves chlorine; if the temperature be raised to $140^{\circ} \mathrm{F}$., the liquor becomes bright, and of a brownish-yellow colour. Sulphuric acid diluted with four times its bulk of water does not act upon it cold. At $212^{\circ} \mathrm{F}$. it dissolves slowly, and the solution is of a reddish-violet colour; this colour indicates manganese of a higher state of oxidizement than manganous oxide, but it occurs only with the chatoyant portions of the specimen.

Nitric acid acts upon it with difficulty, but oxalic acid when heated dissolves it completely; when the solution is suffered to evaporate spontaneously, granular crystals of oxalate of manganese and peroxalate of iron are deposited.

By analysis this mineral yielded-

\begin{tabular}{|c|c|}
\hline Phosphoric acid $\ldots \ldots \ldots$ & $41 \cdot 25$ \\
\hline Peroxide of iron $\ldots \ldots \ldots$ & $25 \cdot 62$ \\
\hline Protoxide of manganese. . & $23 \cdot 08$ \\
\hline Peroxide of manganese & $1 \cdot 06$ \\
\hline Soda $\ldots \ldots \ldots \ldots$ & $5 \cdot 47$ \\
\hline Silica $\ldots \ldots \ldots \ldots$ & 0.60 \\
\hline Water ............ & $2 \cdot 65$ \\
\hline
\end{tabular}

M. Damour proposes the name of alluaudite for this mineral, in honour of M. Alluaud, well-known for attachment to the sciences. -Ibid. 